\title{
Pengaruh Kepemimpinan Terhadap Motivasi Kerja Pegawai di Kantor Pelayanan Pajak
}

\author{
${ }^{1}$ Dedi Sugianto, ${ }^{2}$ Juli Alfiani, ${ }^{3}$ Rahmadi, ${ }^{4}$ Eka Sari \\ ${ }^{1-4}$ Program Magister Manajemen, Fakultas Ekonomi, Universitas Islam Sumatera Utara
}

\author{
Article history \\ Received: 18 Nov 2020 \\ Revised: 13 Dec 2020 \\ Accepted: 30 Dec 2020 \\ *Corresponding Author: \\ Dedi Sugianto, Program \\ Studi Magister Manajemen, \\ Fakultas Ekonomi, \\ Universitas Islam Sumatera \\ Utara \\ Email: \\ dedisugianto@gmail.com
}

\begin{abstract}
Abstrak: Pajak bagi pemerintah tidak hanya merupakan sumber pendapatan, tetapi juga merupakan salah satu variabel kebijaksanaan yang digunakan untuk mengatur jalannya perekonomian. Adapun masalah penelitian ini yaitu mengetahui pengaruh kepemimpinan terhadap motivasi kerja pegawai dikantor pelayanan pajak pratama medan belawan. Metode yang digunakan dalam penelitian ini adalah dengan pendekatan survey melalui observasi, wawancara, pembagian kuesioner dan studi dokumentasi. Metode analisis data yang digunakan adalahanalisis regresi linier berganda. Pengaruh langsung kepemimpinan terhadap kinerja pegawai $=0,430$. Pengaruh tidak langsung melalui motivasi kerja $=(0,164) \times(0,486)=0,079$. Total pengaruh $=0,430+0,079=0,509$. Hasil mediasi menunjukkan bahwa nilai pengaruh langsung lebih tinggi dari pada pengaruh tidak langsung, hal ini menunjukkan bahwa motivasi kerja mampu memediasi pengaruh kepemimpinan terhadap kinerja pegawai meski pengaruh mediasinya relatif lemah.
\end{abstract}

Kata Kunci : Kepemimpinan, Motivasi kerja, Pelayanan pajak.

\section{PENDAHULUAN}

Pajak merupakan sumber utama penerimaan negara disamping penerimaan dari sumber migas dan non migas. Optimalisasi penerimaan pajak dikarenakan semakin meningkatnya kebutuhan dana pembangunan. Pajak bagi pemerintah tidak hanya merupakan sumber pendapatan, tetapi juga merupakan salah satu variabel kebijaksanaan yang digunakan untuk mengatur jalannya perekonomian. Menurut Siti (2012) pada prinsipnya pajak bahwa iuran rakyat kepada kas negara berdasarkan Undang-Undang (yang dapat dipaksakan) dengan tidak mendapatkan jasa timbal balik (kontraprestasi) yang langsung dapat ditunjukkan dan digunakan untuk membayar pengeluaran umum. Lebih lanjut Dwi (2012) mengemukakan bahwa pajak adalah kewajiban untuk menyerahkan sebagian dari kekayaan kepada negara disebabkan oleh suatu keadaan, kejadian, dan perbuatan yang memberikan kedudukan tertentu, tetapi bukan sebagai hukuman, menurut peraturan perundang-undangan yang ditetapkan pemerintah, serta dapat dipaksakan, tetapi tidak ada jasa balik dari negara secara langsung, untuk memelihara kesejahteraan umum.

Gambaran mengenai tingkat pencapaian pelaksanaan suatu kegiatan / program / kebijakan dalam mewujudkan sasaran, tujuan, misi dan visi organisasi yang tertuang dalam strategic planning suatu organisasi (Hasibuan, 2002). Berdasarkan pendapat di atas dapat disimpulkan bahwa pengertian kinerja adalah hasil kerja yang dicapai seseorang pegawai terhadap pelaksanaan tugas perkerjaan yang dinilai berdasarkan pada kriteria atau standar penilaian tertentu.

Kepemimpinan yang andal sangat dibutuhkan organisasi demi mencapai tujuannya, karena gaya kepemimpinan adalah suatu proses dalam mempengaruhi kegiatan seseorang atau kelompok dalam usaha pencapaian tujuan. Jadi keberhasilan dalam pencapaian sasaran organisasi sangat bergantung pada peran pemimpinnya. Karena tingkat keberhasilan suatu kinerja meliputi aspek kuantitatif dan kualitatif. Kinerja adalah hasil kerja secara kualitas dan kuantitas yang dicapai oleh seseorang pegawai dalam melaksanakan tugasnya sesuai dengan tanggung jawab yang diberikan kepadanya (Muluk, 2005). 
Berhasil tidaknya suatu organisasi dalam mencapai tujuan sangatlah dipengaruhi oleh faktor manusia sebagai sumberdaya (resources) yang ada dalam suatu Instansi, dengan kata lain untuk mewujudkan tercapainya tujuan tersebut maka dapat dilihat dari kepuasan kerja pegawai dalam menjalankan tugas-tugas yang diberikan Instansi kepada pegawainya. Instansi dituntut untuk dapat mengelola sumberdaya manusia menjadi tenaga kerja yang efektif serta dapat mengarahkan sumberdaya manusia yang tersedia menuju kearah tujuan Instansi. Fungsi Gaya kepemimpinan yang merupakan salah satu peran pemimpin adalah untuk mengajak bawahannya mau memberikan pengabdiannya dalam pencapaian tujuan organisasi, sesuai dengan gaya kepemimpinan bawahan secara maksimal. Dengan kata lain, bahwa Gaya kepemimpinan dalam organisasi merupakan suatu faktor yang menentukan atas berhasil tidaknya suatu organisasi atau suatu usaha.

Dengan motivasi dan pemberian daya penggerak yang menciptakan kegairahan seseorang agar mereka mau bekerja sama, bekerja efektif dan terintegrasi dengan segala daya upayanya untuk mencapai kepuasan Hasibuan (2005). Jadi motivasi mempersoalkan bagaimana caranya mengarahkan daya dan potensi bawahannya, agar mau bekerja sama secara produktif, berhasil mencapai dan mewujudkan tujuan yang telah ditentukan. Pentingnya motivasi karena motivasi adalah hal yang menyebabkan, menyalurkan dan mendukung perilaku manusia, supaya mau bekerja giat dan antusias mencapai hasil yang optimal.

\section{METODOLOGI PENELITIAN}

Pengumpulan data dalam penelitian ini menggunakan pendekatan kuantitatif dengan penghitungan variable dan populasi terkait. Dimana lokasi penelitian dilakukan di Kantor Pelayanan Pajak Pratama Medan Belawan. Jalan KL Yos Sudarso Km 8,2 Medan20241.Objek penelitian ini adalah kepemimpinan, komitmen organisasi dan budaya organisasi sebagai variabel independent dan motivasi, kinerja pegawai sebagai variabel dependent. Adapun populasi yang dijadikan sampel dalam penelitian ini adalah seluruh pegawai di Kantor Pelayanan Pajak Pratama Medan Belawan yang berjumlah 111 orang. Besarnya sampel dalam penelitian ini ditentukan teori Slovin dengan rumus sebagai berikut:

$$
\mathrm{n}=\frac{\mathrm{N}}{\mathrm{Ne}^{2}+1}
$$

dimana:

$\mathrm{n}=$ jumlah elemen / anggota sampel

$\mathrm{N}=$ jumlah elemen / anggota populasi

$\mathrm{e}=$ error level (tingkat kesalahan) (catatan: umumnya digunakan $1 \%$ atau $0,01,5 \%$ atau 0,05, dan $10 \%$ atau 0,1) (catatan dapat dipilih oleh peneliti dan peneliti memilih $1 \%)$.

Populasi yang terdapat dalam penelitian ini berjumlah 111 dan presisi yang ditetapkan atau tingkat signifikansi 0,1, maka besarnya sampel pada penelitian ini adalah : 


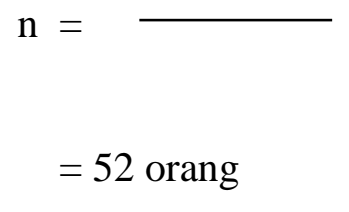

\section{Teknik Pengumpulan Data}

1. Kuesioner/Angket Penelitian yaitu dengan memberikan daftar pertanyaan/angket penelitian sesuai dengan data yang diinginkan kepada para responden yang berjumlah 107 orang.

2. Studi Perpustakaan, yaitu memperoleh data pendukung dalam penelitian ini berdasarkan pada buku-buku, karya ilmiah yang relevan terhadap penelitian.

3. Pengukuran Instrumen yaitu engukuran instrume menggunakan skala likert's.

\section{Teknik Analisis Data}

Pengujian kualitas data dalam penelitian ini menggunakan uji validitas dan reliabilitas, yaitu:

a. Uji Validitas

Pada penelitian ini pengujian dilakukan dengan program SPSS, dan untuk uji validitas dengan menggunakan korelasi Bivariate Pearson (Produk Momen Pearson) dan Corrected Item-Total Correlation.

b. Uji Reliabilitas

Dalam melakukan uji reliabilitas digunakan metode Cronbach's Alpha dengan bantuan program SPSS, menurut Priyatno (2012) menyebutkan metode alpha sangat cocok digunakan pada skor berbentuk skala. Santosa (2005:112) mengatakan suatu kuesioner dikatakan reliabel jika Cronbach Alpha lebih besar dari 0,6.

c. Uji Normalitas

Uji Normalitas akan menguji data variabel bebas (X) dan data variabel terikat (Y) pada persamaan regresi yang dihasilkan, apakah berdistribusi normal atau berdistribusi tidak normal.

d. Uji Multikolinearitas

Menurut Ghozali (2013:105) uji multikolinearitas bertujuan untuk menguji apakah model regresi ditemukan adanya korelasi antar variabel bebas (independen).

e. Uji Heteroskedastisitas

Uji heterokedastisitas bertujuan untuk menguji apakah model regresi terjadi kesamaan varians dari residual satu pengamatan ke pengamatan yang lain.

\section{Analisis Regresi}

Dalam penelitian ini digunakan tiga jenis analisis regresi yaitu regresi berganda dan hierarchical regression yang dijelaskan sebagai berikut:

1. Regresi Berganda

Menguji pengaruh kepemimpinan, komitmen organisasi, budaya organisasi dan motivasi kerja terhadap kinerja pegawai dengan persamaan sebagai berikut:

$\mathrm{Y}=\beta_{0}+\beta_{1} \mathrm{X}_{1}+\beta_{2} \mathrm{X}_{2}+\beta_{3} \mathrm{X}_{3}+\beta_{4} \mathrm{I}+\mathrm{e}$

Keterangan:

Y

= Kinerja Pegawai 


$$
\begin{array}{ll}
\beta_{0} & =\text { Konstanta } \\
\beta_{1,2,3 \text { dan } 4} & =\text { Koefisien Regesi } \\
\mathrm{X}_{1} & =\text { Kepemimpinan } \\
\mathrm{X}_{2} & =\text { Komitmen organisasi } \\
\mathrm{X}_{3} & =\text { Budaya organisasi } \\
\mathrm{I} & =\text { Motivasi } \\
\mathrm{e} & =\text { Pengaruh Variabel lain }
\end{array}
$$

2. Menguji pengaruh kepemimpinan,komitmen dan budaya organisasi terhadap motivasi kerja dengan persamaan sebagai berikut :

$$
I=\beta_{0}+\beta_{1} X_{1}+\beta_{2} X_{2}+\beta_{3} X_{3}+e
$$

Keterangan:

$$
\begin{aligned}
& \text { I }=\text { Motivasi } \\
& \beta_{0} \quad=\text { Konstanta } \\
& \beta_{1,2, \text { dan } 3}=\text { Koefisien Regesi } \\
& \mathrm{X}_{1} \quad=\text { Kepemimpinan } \\
& \mathrm{X}_{2} \quad=\text { Komitmen organisasi } \\
& \mathrm{X}_{3} \quad=\text { Budaya organisasi } \\
& \mathrm{e} \quad=\text { Pengaruh Variabel lain }
\end{aligned}
$$

3. Koefisien Determinan

Koefisien determinan $\left(\mathrm{R}^{2}\right)$ berguna untuk mengetahui seberapa besar kontribusi satu atau beberapa variabel terhadap variabel lain.

$$
\mathbf{F}=\frac{\mathbf{R}^{2}(\mathbf{K}-\mathbf{1})}{\mathbf{1}-\mathbf{R}^{2} /(\mathbf{n}-\mathbf{k})}
$$

Keterangan:

$$
\begin{array}{ll}
\mathrm{F} & =\text { Uji F } \\
\mathrm{R}^{2} & =\text { Koefisien Determinan } \\
\mathrm{K} & =\text { Jumlah Variabel } \\
\mathrm{n} & =\text { Jumlah Responden }
\end{array}
$$

\section{HASIL DAN PEMBAHASAN}

Tabel 1. Statistik Deskriptif

\begin{tabular}{llcccccc}
\hline \multirow{2}{*}{ Instrumen } & \multicolumn{6}{c}{ Frekwensi (Persentase) } \\
\cline { 3 - 8 } \multicolumn{1}{c}{} & $\mathbf{5}$ & $\mathbf{4}$ & $\mathbf{3}$ & $\mathbf{2}$ & $\mathbf{1}$ & Total \\
\hline 1. & $\mathrm{KP} 1$ & 23,1 & 73,1 & 3,8 & 0 & 0 & 100 \\
2. & $\mathrm{KP} 2$ & 25,0 & 71,2 & 3,8 & 0 & 0 & 100 \\
3. & $\mathrm{KP} 3$ & 21,2 & 71,2 & 7,7 & 0 & 0 & 100 \\
4. & $\mathrm{KP} 4$ & 23,1 & 57,7 & 19,2 & 0 & 0 & 100 \\
5. & $\mathrm{KP} 5$ & 28,8 & 57,7 & 13,5 & 0 & 0 & 100 \\
6. & $\mathrm{KP} 6$ & 17,3 & 73,1 & 9,6 & 0 & 0 & 100
\end{tabular}




\begin{tabular}{llcccccc}
\hline 7. & KP7 & 30,8 & 69,2 & 0 & 0 & 0 & 100 \\
8. & KP8 & 30,8 & 69,2 & 0 & 0 & 0 & 100 \\
9. & KP9 & 32,7 & 57,7 & 9,6 & 0 & 0 & 100 \\
10. & KP10 & 30,8 & 59,6 & 9,6 & 0 & 0 & 100 \\
\hline 1. & K1 & 26,9 & 71,2 & 1,9 & 0 & 0 & 100 \\
2. & K2 & 25,0 & 69,2 & 5,8 & 0 & 0 & 100 \\
3. & K3 & 21,2 & 59,6 & 19,2 & 0 & 0 & 100 \\
4. & K4 & 23,1 & 57,7 & 19,2 & 0 & 0 & 100 \\
5. & K5 & 30,8 & 69,2 & 0 & 0 & 0 & 100 \\
6. & K6 & 28,8 & 69,2 & 1,9 & 0 & 0 & 100 \\
7. & K7 & 19,2 & 69,2 & 11,5 & 0 & 0 & 100 \\
8. & K8 & 21,2 & 67,3 & 11,5 & 0 & 0 & 100 \\
9. & K9 & 21,2 & 71,2 & 5,8 & 1,9 & 0 & 100 \\
10. & K10 & 21,2 & 73,1 & 5,8 & 0 & 0 & 100 \\
\hline
\end{tabular}

1. Jawaban responden mengenai hasil penilaian kinerja pegawai selama ini dapat dijadikan tingkat ukuran berhasil tidaknya kinerja pegawai sebanyak 30,8\% menjawab sangat setuju, setuju sebanyak 69,2\%.

2. Jawaban responden mengenai pegawai tidak melakukan pekerjaan lain dalam waktu jam kerja sebanyak 32,7\% menjawab sangat setuju, setuju sebanyak $57,7 \%$ dan kurang setuju sebanyak $9,6 \%$.

3. Jawaban responden mengenai perhatian pimpinan kepada pegawai akan meningkatakan kinerjanya sebanyak 30,8\% menjawab sangat setuju, setuju sebanyak 59,6\% dan kurang setuju sebanyak 9,6\%.

4. Jawaban responden mengenai pimpinan selalu memberikan instruksi pekerjaan secara jelas dan spesifik sebanyak 26,9\% menjawab sangat setuju, setuju sebanyak $71,2 \%$ dan kurang setuju sebanyak $1,9 \%$.

5. Jawaban responden mengenai pimpinan mendelegasikan secara keseluruhan keputusan yang diambil pegawai sebanyak $25,0 \%$ menjawab sangat setuju, setuju sebanyak 69,2\% dan kurang setuju sebanyak 5,8\%.

6. Jawaban responden mengenai pimpinan selalu mengawasi penyelesaian tugas pegawai sebanyak 21,2\% menjawab sangat setuju, setuju sebanyak 59,6\% dan kurang setuju sebanyak 19,2\%.

7. Jawaban responden mengenai pimpinan selalu mendukung kemajuan pegawai sebanyak $23,1 \%$ menjawab sangat setuju, setuju sebanyak $57,7 \%$ dan kurang setuju sebanyak $19,2 \%$.

8. Jawaban responden mengenai pimpinan selalu memberikan wewenang kepada pegawai sebanyak 30,8\% menjawab sangat setuju, setuju sebanyak 69,2\%.

9. Jawaban responden mengenai pimpinan selalu membuat aturan/prosedur yang harus ditaati dalam melaksanakan pekerjaan sebanyak $28,8 \%$ menjawab sangat setuju, setuju sebanyak 69,2\% dan kurang setuju sebanyak 1,9\%. 
10. Jawaban responden mengenai pimpinan selalu memperhatikan ke sejahteraan pegawai sebanyak 19,2\% menjawab sangat setuju, setuju sebanyak $69,2 \%$ dan kurang setuju sebanyak $11,5 \%$.

11. Jawaban responden mengenai pimpinan selalu memudahkan dan mendukung upaya bawahan dalam penyelesaian pekerjaan sebanyak $21,2 \%$ menjawab sangat setuju, setuju sebanyak $67,3 \%$ dan kurang setuju sebanyak $11,5 \%$.

12. Jawaban responden mengenai pimpinan selalu memberikan motivasi kepada pegawai untuk bekerja dan berprestasi lebih baik sebanyak 21,2\% menjawab sangat setuju, setuju sebanyak $71,2 \%$, kurang setuju sebanyak $5,8 \%$ dan tidak setuju sebanyak $1,9 \%$.

13. Jawaban responden mengenai pimpinan memberikan pujian ketika pegawai berhasil menyelesaikan pekerjaannya sebanyak $21,2 \%$ menjawab sangat setuju, setuju sebanyak $73,1 \%$ dan kurang setuju sebanyak 5,8\%.

\section{Uji Kualitas Data}

Tabel 2. Uji Validitas Variabel

\begin{tabular}{llccc}
\hline \multicolumn{1}{l}{ Instrumen } & r-hitung & r-tabel & Keterangan \\
\hline 1) & K1 & 0.611 & 0.273 & Valid \\
2) & K2 & 0.487 & 0.273 & Valid \\
3) & K3 & 0.632 & 0.273 & Valid \\
4) & K4 & 0.450 & 0.273 & Valid \\
5) & K5 & 0.536 & 0.273 & Valid \\
6) & K6 & 0.768 & 0.273 & Valid \\
7) & K7 & 0.518 & 0.273 & Valid \\
8) & K8 & 0.401 & 0.273 & Valid \\
9) & K9 & 0.722 & 0.273 & Valid \\
10) & K10 & 0.457 & 0.273 & Valid \\
\hline 1. & KP1 & 0.463 & 0.273 & Valid \\
2. & KP2 & 0.677 & 0.273 & Valid \\
3. & KP3 & 0.561 & 0.273 & Valid \\
4. & KP4 & 0.603 & 0.273 & Valid \\
5. & KP5 & 0.535 & 0.273 & Valid \\
6. & KP6 & 0.598 & 0.273 & Valid \\
7. & KP7 & 0.706 & 0.273 & Valid \\
8. & KP8 & 0.635 & 0.273 & Valid \\
9. & KP9 & 0.434 & 0.273 & Valid \\
10. & KP10 & 0.580 & 0.273 & Valid \\
\hline & & & &
\end{tabular}




\section{Reliabilitas}

Tabel 3. Uji Reliabilitas Variabel

\begin{tabular}{cccc}
\hline Variabel & $\begin{array}{c}\text { Cronbach's } \\
\text { Alpha }\end{array}$ & $\begin{array}{c}\text { Batas } \\
\text { Reliabilitas }\end{array}$ & Keterangan \\
\hline Kepemimpinan (X1) & 0.722 & 0.6 & Reliabel \\
Kinerja Pegawai (Y) & 0.731 & 0.6 & Reliabel \\
& & & Reliabel \\
& & & Reliabel \\
\hline
\end{tabular}

Dari data tabel 5.6 di atas dapat dilihat bahwa hasil perhitungan uji reliabilitas menunjukkan alpha cronbach's pada masing-masing kolom variabel tersebut lebih besar dari 0,6 (batas reliabilitas) maka dapat dinyatakan instrumen tersebut reliabel.

\section{Pengujian Hipotesis}

\section{Pengujian Hipotesis dengan Uji F}

Tabel 4. Hasil Uji Simultan (Uji F) Persamaan 1

\begin{tabular}{llr|r|r|r|r}
\multicolumn{7}{c}{ ANOVA $^{\mathrm{a}}$} \\
\multirow{2}{*}{ Model } & $\begin{array}{c}\text { Sum of } \\
\text { Squares }\end{array}$ & \multicolumn{1}{c|}{ df } & Square & \multicolumn{1}{c}{ F } & Sig. \\
\hline 1 & Regression & 312.715 & 3 & 104.238 & 17.247 & $.000^{\mathrm{b}}$ \\
\cline { 2 - 7 } & Residual & 290.112 & 48 & 6.044 & & \\
\cline { 2 - 7 } & Total & 602.827 & 51 & & & \\
\hline
\end{tabular}

Berdasarkan uji $\mathrm{F}$ persamaan 1 atau uji Anova atau uji simultan di atas diperoleh $\mathrm{F}$ hitung sebesar 17,247 pada $\alpha=5 \%$ atau 0,05 dengan tingkat signifikan 0,000 karena nilai probabilitas $(0,000)$ jauh lebih kecil dari 0,05 maka model regresi dapat dipakai untuk memprediksi bahwa fasilitas kerja dan kepemimpinan sebagai variabel independen secara bersama-sama (simultan) berpengaruh terhadap motivasi kerja. Dengan kata lain, kepemimpinan, komitmen organisasi dan budaya organisasi secara simultan mempunyai pengaruh yang positif dan signifikan terhadap motivasi kerja, karena $\mathrm{F}$ hitung $>\mathrm{F}$ tabel yakni $17,247>2,80$. Dari hasil persamaan regresi linier berganda tersebut di atas dapat dianalis sebagai berikut ini:

Uji Hipotesis 1

Dari hasil perhitungan uji secara parsial diperoleh nilai t hitung sebesar 1,354 dan nilai signifikansi sebesar 0,182. Karena nilai signifikansi lebih besar dari 5\% maka hipotesis (H1) ditolak, yang berarti terdapat pengaruh signifikan positif antara variabel kepemimpinan terhadap variabel motivasi kerja. Hal ini menunjukkan bahwa perusahaan yang mempunyai/memiliki kepemimpinan yang lengkap tidak mampu memotivasi pegawai dalam bekerja.

\section{Hasil Analisis Mediasi}

Pengaruh Kepemimpinan terhadap Kinerja Pegawai melalui Motivasi Kerja 
Pengaruh langsung kepemimpinan terhadap kinerja pegawai $=0,430$. Pengaruh tidak langsung melalui motivasi kerja $=(0,164) \times(0,486)=0,079$. Total pengaruh $=0,430+0,079$ $=0,509$. Hasil mediasi menunjukkan bahwa nilai pengaruh langsung lebih tinggi dari pada pengaruh tidak langsung, hal ini menunjukkan bahwa motivasi kerja mampu memediasi pengaruh kepemimpinan terhadap kinerja pegawai meski pengaruh mediasinya relatif lemah.

\section{Pengaruh Kepemimpinan terhadap Motivasi}

Pada pengujian hipotesis berdasarkan hasil perhitungan dapat dikatakan bahwa kepemimpinan tidak berpengaruh terhadap motivasi kerja di Kantor Pelayanan Pajak Pratama Medan Belawan. Dengan demikian secara simultan hasil penelitian ini tidak sesuai dengan teori yang menyatakan bahwa kepemimpinan signifikan terhadap motivasi kerja. Pengaruh tersebut menunjukkan jika kepemimpinan diterapkan di Kantor Pelayanan Pajak Pratama Medan Belawan, maka tidak akan meningkatkan motivasi kerja. Artinya bahwa kepemimpinan belum memiliki perananan yang penting dalam meningkatkan motivasi kerja.

\section{KESIMPULAN}

Sesuai hasil analisis penelitian maka dapat diamil kesimpulan sesuai tujuan penelitian yang dikemukakan.

1. Kepemimpinan tidak berpengaruh terhadap motivasi kerja Kantor Pelayanan Pajak Pratama Medan Belawan, hal ini didukung hasil analisis $t$ hitung < $\mathrm{t}$-tabel $(1,354<$ 2,011) pada $\mathrm{n}=52$ pada taraf sifgifikansi $95 \%$.

2. Nilai F-hitung > F tabel $(21,751>2,57)$ hal ini menyatakan bahwa secara bersamasama (multiple) terdapat pengaruh positif dan signifikan kepemimpinan, terhadap kinerja pegawai Kantor Pelayanan Pajak Pratama Medan Belawan. Dengan demikian hipotesis yang diajukan diterima kebenarannya.

\section{DAFTAR PUSTAKA}

Dwi Sunar Prasetyono. 2012. Buku Pintar Pajak. Jakarta: Laksana

Ghozali, Imam. 2013. Aplikasi AnalisisMultivariate dengan Program IBM SPSS 21 Update PLS Regresi. Semarang: Badan Penerbit Universitas Diponegoro

Hasibuan, Malayu SP. 2002. Manajemen Sumber Daya Manusia. Jakarta: PT. Bumi Akasara

Muluk, M.R.K. 2005. Budaya Organisasi Pelayanan Publik, Jurnal Manajemen Pelayanan Kesehatan 08 (1) : 8-20

Priyatno, Duwi. 2012. Cara Kilat Belajar Analisis Data SPSS 20. Yogyakarta: Andi.

Schuler Randal S and Jackson Susan E, alih bahasa Prawira Hie. 2007. Manajemen Sumber Daya Manusia. Jakarta: Penerbit Erlangga

Santoso, S. 2015. SPSS20 Pengolahan Data Statistik di Era Informasi. Jakarta: PT. Alex Media Komputindo, Kelompok Gramedia.

Siti Resmi. 2012. Perpajak, Teori dan Praktek. Jakarta: Salemba Empat 
Dedi Sugianto et al, 2021 